\title{
Serological evidence of exposure to tick-borne agents in opossums (Didelphis spp.) in the state of São Paulo, Brazil
}

Evidência sorológica de exposição a agentes transmitidos por carrapatos em gambás (Didelphis spp.) no estado de São Paulo, Brasil

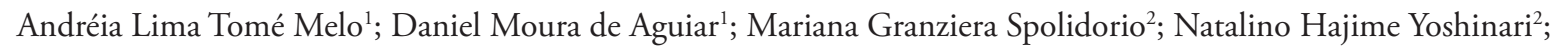
Eliana Reiko Matushima²; Marcelo Bahia Labruna²; Mauricio Claudio Horta ${ }^{3 *}$

\author{
${ }^{1}$ Universidade Federal do Mato Grosso - UFMT, Cuiabá, MT, Brasil \\ ${ }^{2}$ Universidade de São Paulo - USP, São Paulo, SP, Brasil \\ ${ }^{3}$ Universidade Federal do Vale do São Francisco - Univasf, Petrolina, PE, Brasil
}

Received November 5, 2015

Accepted March 29, 2016

\begin{abstract}
This work involved a serological investigation of tick-borne pathogens in opossums in eight municipalities of the state of São Paulo, Brazil. Serum samples from 109 opossums (91 Didelphis aurita and 18 Didelphis albiventris) were tested to detect antibodies to Rickettsia rickettsii (Taiaçu strain, 1:64 cut-off) and Ehrlichia canis (São Paulo strain, 1:40 cut-off), by indirect immunofluorescence assay (IFA); and against Borrelia burgdorferi (strain G39/40) by enzyme-linked immunosorbent assay (ELISA). The presence of antibodies to anti-R. rickettsii, anti-E. canis and anti-B. burgdorferi was detected in $32(29.35 \%), 16(14.67 \%)$ and $30(27.52 \%)$ opossums, respectively. Opossum endpoint titers ranged from 64 to 1,024 for $R$. rickettsii, from 40 to 160 for $E$. canis, and from 400 to $>51,200$ for B. burgdorferi. These serological results suggest that opossums have been exposed to Rickettsia spp., Ehrlichia spp., and B. burgdorferi-related agents in the state of São Paulo. Our study underscores the need for further research about these agents in this study area, in view of the occurrence of Spotted Fever and Baggio-Yoshinari Syndrome disease in humans in the state of São Paulo, Brazil.
\end{abstract}

Keywords: Didelphis albiventris, Didelphis aurita, Rickettsia, Ehrlichia, Borrelia, ticks.

\section{Resumo}

O presente estudo investigou evidência sorológica de agentes transmitidos por carrapatos em gambás em oito municípios do Estado de São Paulo, Brasil. Amostras de soro de 109 gambás (91 Didelphis aurita e 18 Didelphis albiventris) foram testadas para detecção de anticorpos contra Rickettsia rickettsii (cepa Taiaçu, ponto de corte 1:64) Ehrlichia canis (cepa São Paulo, ponto de corte 1:40), pela reação de imunofluorescência indireta (RIFI); e contra Borrelia burgdorferi (cepa G39/40) pelo teste imunoenzimático (ELISA). A presença de anticorpos anti-R. rickettsii, anti-E. canis e anti-B. burgdorferi foi detectada em 32 (29,35\%), $16(14,67 \%)$ e 30 (27,52\%) gambás, respectivamente. Os títulos finais variaram de 64 a 1.024 para $R$. rickettsii, de 40 a 160 para E. canis, e de 400 a $>51.200$ para B. burgdorferi. Esses resultados sugerem que os gambás foram expostos a agentes relacionados à Rickettsia spp., Ehrlichia spp., e B. burgdorferi no Estado de São Paulo. Neste estudo salienta a necessidade de novas pesquisas sobre esses agentes nessas áreas de trabalho, devido à ocorrência da Febre Maculosa e da Síndrome Baggio-Yoshinari em humanos no Estado de São Paulo, Brasil.

Palavras-chave: Didelphis albiventris, Didelphis aurita, Rickettsia, Ehrlichia, Borrelia, carrapatos.

\section{Introduction}

Worldwide tick-borne diseases have been highlighted in both human and veterinary medicine. Various tick species act as vectors of several pathogens, and many wild animals act as reservoirs for these agents. Therefore, rickettsiosis, ehrlichiosis, and borreliosis

*Corresponding author: Mauricio Claudio Horta. Colegiado de Medicina Veterinária, Universidade Federal do Vale do São Francisco - Univasf, Rodovia BR 407, Km 12, Lote 543, Projeto de Irrigação Senador Nilo Coelho, s/n, C1, CEP 56300-990, Petrolina, PE, Brasil. e-mail: horta.mc@hotmail.com have been reported around the world to cause illness in animals and humans (CASTELLAW et al., 2011).

Ticks are considered vectors of a large number of infectious agents (HOOGSTRAAL, 1967). Only a few of the approximately 825 species of ticks described worldwide are directly relevant to public health, because of the possibility of these ticks parasitizing humans (OLIVER, 1989). However several other species that have never been described in humans may play an important, albeit 
indirect role in public health because they contribute to the enzootic maintenance of infectious agents in nature (HOOGSTRAAL, 1967). In this context, the genera Rickettsia, Ehrlichia and Borrelia are important tick borne agents that cause disease in humans and animals (DUMLER et al., 2001; KRUPKA et al., 2007; PAROLA et al., 2013).

In Brazil, opossums are infested with different species of ticks and can often act as amplifier hosts of some pathogens, such as $R$. rickettsii (HORTA et al., 2009), which is the world's most pathogenic species of Rickettsia and is responsible for causing Brazilian Spotted Fever (BSF) (PAROLA et al., 2013). These animals are abundant in all areas endemic for BSF, where they present high antibody titers to $R$. rickettsii (HORTA et al., 2007) and are usually infested with ticks of the $A$. cajennense complex, the most important vector in South America (LABRUNA, 2009).

As for the genus Ehrlichia, there are few studies about the presence of antibodies in opossums. Animals seropositive to Ehrlichia chaffeensis have been reported in the United States (CASTELLAW et al., 2011). On the other hand, Lyme disease, a common zoonosis in the northern hemisphere (United States, Europe and Asia), is considered an infectious disease caused by spirochetes of the Borrelia burgdorferi sensu lato complex which is transmitted by ticks of the Ixodes ricinus complex (STEERE, 2001). In the case of borreliosis, this disease can be caused by a number of species of worldwide distribution, such as Borrelia burgdorferi (United States and Europe); Borrelia garinii and Borrelia afzelii (Europe), and Borrelia japonica (Asia) (STEERE, 2001; FELSENFELD, 1965; BARANTON et al., 1992). These species were isolated from Ixodes sp. ticks and another spirochete, called Borrelia lonestari, found in the United States, was isolated from Amblyomma americanum (BARBOUR et al., 1996). In Brazil, the disease is known as Baggio-Yoshinari Syndrome (BYS) or Lyme-like disease, and the first cases similar to this disease in the country were described in 1992 in siblings, who developed erythema migrans, flu-like symptoms and arthritis after being bitten by ticks. However, B. burgdorferi has so far not been isolated in this country. Specimens of the genera Ixodes and Amblyomma naturally infected with unidentified spirochetes have been found in areas where Lyme-like disease has been reported (YOSHINARI et al., 2010).

This work involved a serological evaluation of tick-borne agents (Ehrlichia spp., Rickettsia spp. and Borrelia spp.) in blood collected from opossums (Didelphis spp.) in the state of São Paulo, Brazil.

\section{Materials and Methods}

This study was conducted in eight municipalities (Barueri, Biritiba Mirim, Cotia, Osasco, Salesópolis, São Bernardo do Campo, São Paulo, and Sorocaba) in the state of São Paulo, Brazil (Figure 1). Free-living opossums were captured between 2003 and 2008. The opossums were anesthetized with $15-30 \mathrm{mg} / \mathrm{kg}$

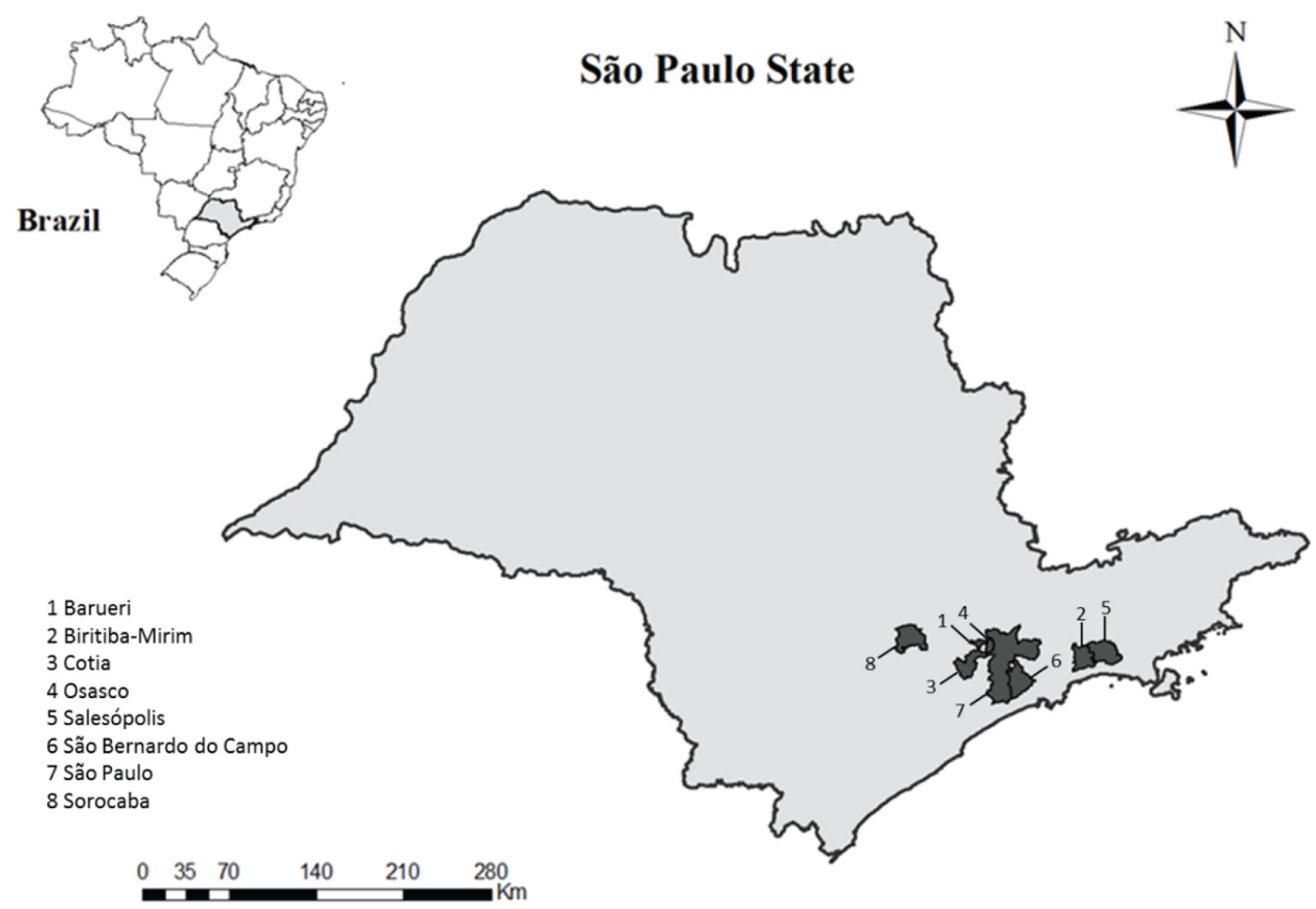

Figure 1. Geographic locations of the 8 municipalities in which the opossums were caught. State of São Paulo, Brazil. 
of ketamine prior to drawing blood samples. The serum was prepared individually by centrifugation ( $3.000 \mathrm{~g}$ for 15 minutes), and stored at $-20^{\circ} \mathrm{C}$ for the immunofluorescence assay (IFA) and enzyme-linked immunosorbent (ELISA) assays.

This study was approved by the Ethics Committee on Animal Use of the University of São Paulo (under Protocol FMVZ 301/2003, ICB 495/CEP/2003), and by the Brazilian Institute of Environment and Renewable Natural Resources - IBAMA (under Protocol No. 02027.023912/2002)

The IFA was used to detect antibodies to Ehrlichia spp. and Rickettsia spp. Anti-Ehrlichia spp. antibodies were evaluated using the São Paulo strain of E. canis with a cut-off point at an initial dilution of 1:40 (AGUIAR et al., 2007). Anti-Rickettsia spp. antibodies were evaluated using the Taiaçu strain of $R$. rickettsii, with an initial dilution of 1:64 as previously described (PINTER \& LABRUNA, 2006). Each slide contained serum previously shown to be non-reactive (negative control) and serum known to be reactive (positive control, obtained by experimentally infection of the agents in opossums). Anti-Borrelia antibodies were evaluated by ELISA using the North American strain G39/40 of B. burgdorferi as antigen (JOPPERT et al., 2001).

\section{Results}

Sera samples were obtained from 109 young and adult opossums, i.e., 91 Didelphis aurita and 18 Didelphis albiventris. The presence of anti-Rickettsia sp.. anti-Ehrlichia sp., and anti-B. burgdorferi antibodies was detected in 32 (29.35\%), 16 (14.67\%) and $30(27.52 \%)$ opossums, respectively (Table 1$)$. Opossum endpoint titers ranged from 64 to 1,024 for $R$. rickettsii, from 40 to 160 for E. canis, and from 400 to $>51,200$ for B. burgdorferi.

\section{Discussion}

This study detected the presence of antibodies against Rickettsia spp., Ehrlichia spp. and B. burgdorferi in free-living opossums in the state of São Paulo. In Brazil, serological studies in opossums infected experimentally with $R$. rickettsii, $R$. parkeri, $R$. bellii, and $R$. felis have shown that these animals have enough seroconversion to be positive by IFA (HORTA et al., 2009, 2010). Studies on free-living opossums in the states of São Paulo and Minas Gerais detected reactivity rates of 59.5\% (56/94) and 42.1\% (16/38), respectively, against Rickettsia-specific antigen (HORTA et al., 2007; MILAGRES et al., 2010). More recently Silveira et al. (2015) found free living opossums seroreactive to Rickettsia spp. ( $R$. parkeri, $R$. rickettsii, $R$. amblyommii and $R$. rhipicephali) from Paulicéia, state of São Paulo. Although our results indicated lower percentages than those found in another studies, we found evidence of rickettsial infection circulating among opossums in Brazil, an important synanthropic animal commonly present in areas endemic for BSF. Horta et al. (2009) had already demonstrated that $R$. rickettsii is able to infect opossums without clinical signs and to develop rickettsemia that can cause infection in guinea pigs and ticks. These results consistently demonstrate that opossums can serve as amplifier hosts for the horizontal transmission of this pathogen to $A$. cajennense ticks. Thus, it can be inferred that the participation of opossums in the epidemiology of the disease is very important for the maintenance of the agent in nature, not only in ticks but also in vertebrates hosts, including humans.

This study reports the presence of anti-Ehrlichia spp. antibodies in opossums. Evidence of the exposure of opossums to E. chaffeensis has been reported in the USA (CASTELLAW et al., 2011). Although research into Ehrlichia spp. infections in opossums are scanty, our results indicate the possibility that they occur due to the presence of vector ticks. The existence of cross-reactivity observed in the IFA among the species of the genus Ehrlichia (HARRUS \& WANER, 2011) implies the possibility that an unrecognized ehrlichial agent is circulating among these animals. To date, only E. canis and an ehrlichial agent related to cattle and Rhipicephalus (Boophilus) microplus ticks have been isolated in Brazil (CABEZASCRUZ et al., 2012; AGUIAR et al., 2013, 2014).

Our results support the evidence of $B$. burgdorferi infection in opossums (27.52\%). Similar results were observed in the state of Minas Gerais, where the presence of antibodies against $B$. burgdorferi was detected in 7.69\% opossums (MONTANDON et al., 2014). Other studies in Brazil have reported humans and animals seropositive for B. burgdorferi (YOSHINARI et al., 2010; CORRADI et al., 2006; MADUREIRA et al., 2007; MONTANDON et al., 2014), demonstrating different prevalence rates in dispersed areas and showing that both domestic and wild animals are becoming

Table 1. Presence of anti-R. rickettsii, anti-E. canis, and anti-B. burgdorferi antibodies in opossums (D. albiventris and Didelphis aurita) from the state of São Paulo, Brazil.

\begin{tabular}{|c|c|c|c|c|c|c|}
\hline \multirow{2}{*}{ Municipality } & \multicolumn{2}{|c|}{ Rickettsia rickettsii } & \multicolumn{2}{|c|}{ Ehrlichia canis } & \multicolumn{2}{|c|}{ Borrelia burgdorferi } \\
\hline & D. albiventris & D. aurita & D. albiventris & D. aurita & D. albiventris & D. aurita \\
\hline Barueri & - & $0 \%(0 / 1)$ & - & $0 \%(0 / 1)$ & - & $0 \%(0 / 1)$ \\
\hline Biritiba-Mirim & $100 \%(1 / 1)$ & $25 \%(3 / 12)$ & $0 \%(0 / 1)$ & $33.33 \%(4 / 12)$ & $100 \%(1 / 1)$ & $50 \%(6 / 12)$ \\
\hline Cotia & - & $100 \%(1 / 1)$ & - & $0 \%(0 / 1)$ & - & $100 \%(1 / 1)$ \\
\hline Osasco & - & $50 \%(1 / 2)$ & - & $0 \%(0 / 2)$ & - & $50 \%(1 / 2)$ \\
\hline Salesópolis & - & $60 \%(3 / 5)$ & - & $20 \%(1 / 5)$ & - & $40 \%(2 / 5)$ \\
\hline São Bernardo do Campo & $50 \%(1 / 2)$ & $20 \%(1 / 5)$ & $50 \%(1 / 2)$ & $20 \%(1 / 5)$ & $50 \%(1 / 2)$ & $40 \%(2 / 5)$ \\
\hline São Paulo & - & $34 \%(17 / 50)$ & - & $12 \%(6 / 50)$ & - & $26 \%(13 / 50)$ \\
\hline Sorocaba & $20 \%(3 / 15)$ & $6.67 \%(1 / 15)$ & $13.33 \%(2 / 15)$ & $6.67 \%(1 / 15)$ & $20 \%(3 / 15)$ & $0 \%(0 / 15)$ \\
\hline Total & \multicolumn{2}{|c|}{$29.35 \%(32 / 109)$} & \multicolumn{2}{|c|}{$14.67 \%(16 / 109)$} & \multicolumn{2}{|c|}{$27.52 \%(30 / 109)$} \\
\hline
\end{tabular}


infected with a closely related Borrelia spp., although the agents have never been isolated in Brazil.

Our findings reinforce the probable presence of these agents in opossums in eight municipalities in the state of São Paulo and emphasize the need for further research into these pathogens in this study area, in view of the occurrence of BSF and BYS in humans in the state of São Paulo.

\section{Acknowledgements}

This work was supported by the Brazilian research funding agencies FAPESP (São Paulo Research Foundation), CAPES (Federal Agency for the Support and Improvement of Higher Education), and CNPq (National Council for Scientific and Technological Development) through scholarship program and scientific productivity granted to ALTM, DMA and MBL.

\section{References}

Aguiar DM, Cavalcante GT, Pinter A, Gennari SM, Camargo LM, Labruna MB. Prevalence of Ehrlichia canis (Rickettsiales: Anaplasmataceae) in dogs and Rhipicephalus sanguineus (Acari: Ixodidae) ticks from Brazil. J Med Entomol 2007; 44(1): 126-132. http://dx.doi.org/10.1603/00222585(2007)44[126:POECRA]2.0.CO;2. PMid:17294930.

Aguiar DM, Zhang X, Melo ALT, Pacheco TA, Meneses AMC, Zanutto MS, et al. Genetic diversity of Ehrlichia canis in Brazil. Vet Microbiol 2013; 164(3-4): 315-321. http://dx.doi.org/10.1016/j.vetmic.2013.02.015. PMid:23490559.

Aguiar DM, Ziliani TF, Zhang X, Melo ALT, Braga IA, Witter R, et al. A novel Ehrlichia genotype strain distinguished by the TRP36 gene naturally infects cattle in Brazil and causes clinical manifestations associated with ehrlichiosis. Ticks Tick Borne Dis 2014; 5(5): 537-544. http://dx.doi. org/10.1016/j.ttbdis.2014.03.010. PMid:24915874.

Baranton G, Postic D, Saint Girons I, Boerlin P, Piffaretti JC, Assous $\mathrm{M}$, et al. Delineation of Borrelia burgdorferi sensu stricto, Borrelia garinii sp. nov., and group VS461 associated with Lyme borreliosis. Int J Syst Bacteriol 1992; 42(3): 378-383. http://dx.doi.org/10.1099/0020771342-3-378. PMid:1380285.

Barbour AG, Maupin GO, Teltow GJ, Carter CJ, Piesman J. Identification of an uncultivable Borrelia species in the hard tick Amblyomma americanum: possible agent of a Lyme disease-like illness. J Infect Dis 1996; 173(2): 403-409. http://dx.doi.org/10.1093/infdis/173.2.403. PMid:8568302.

Cabezas-Cruz A, Zweygarth E, Ribeiro MFB, Silveira JAG, de la Fuente J, Grubhoffer L, et al. New species of Ehrlichia isolated from Rhipicephalus (Boophilus) microplus shows an ortholog of the E. canis major immunogenic glycoprotein gp36 with a new sequence of tandem repeats. Parasit Vectors 2012; 5(1): 291. http://dx.doi.org/10.1186/17563305-5-291. PMid:23231731.

Castellaw AH, Chenney EF, Varela-Stokes AS. Tick-borne disease agents in various wildlife from Mississippi. Vector Borne Zoonotic Dis 2011; 11(4): 439-442. http://dx.doi.org/10.1089/vbz.2009.0221. PMid:20846016.

Corradi DA, Carvalho VM, Coutinho SD. Anticorpos para Borrelia burgdorferi em indivíduos que trabalham com animais silvestres. Arq Bras Med Vet Zootec 2006; 58(5): 966-968. http://dx.doi.org/10.1590/ S0102-09352006000500042.
Dumler JS, Barbet AF, Bekker CPJ, Dasch GA, Palmer GH, Ray SC, et al. Reorganization of genera in the families Rickettsiaceae and Anaplasmataceae in the order Rickettsiales: unification of some species of Ehrlichia with Anaplasma, Cowdria with Ehrlichia and Ehrlichia with Neorickettsia, descriptions of six new species combinations and designation of Ehrlichia equi and 'HGE agent' as subjective synonyms of Ehrlichia phagocytophila. Int J Syst Evol Microbiol 2001; 51(6): 2145-2165. http:// dx.doi.org/10.1099/00207713-51-6-2145. PMid:11760958.

Felsenfeld O. Borreliae, human relapsing fever, and parasite-vector-host relationships. Bacteriol Rev 1965; 29(1): 46-74. PMid:14295985.

Harrus S, Waner T. Diagnosis of canine monocytotropic ehrlichiosis (Ehrlichia canis): an overview. Vet J2011; 187(3): 292-296. http://dx.doi. org/10.1016/j.tvjl.2010.02.001. PMid:20226700.

Hoogstraal H. Ticks in relation to human diseases caused by Rickettsia species. Annu Rev Entomol 1967; 12(1):377-420. http://dx.doi.org/10.1146/ annurev.en.12.010167.002113. PMid:5340723.

Horta MC, Labruna MB, Pinter A, Linardi PM, Schumaker TTS. Rickettsia infection in five areas of the state of São Paulo, Brazil. Mem Inst Oswaldo Cruz 2007; 102(7): 793-801. http://dx.doi.org/10.1590/ S0074-02762007000700003. PMid:18094887.

Horta MC, Moraes-Filho J, Casagrande RA, Saito TB, Rosa SC, Ogrzewalska M, et al. Experimental Infection of opossums Didelphis aurita by Rickettsia rickettsii and evaluation of the transmission of the infection to ticks Amblyomma cajennense. Vector Borne Zoonotic Dis 2009; 9(1): 109-118. http://dx.doi.org/10.1089/vbz.2008.0114. PMid:18945194.

Horta MC, Sabatini GS, Moraes-Filho J, Ogrzewalska M, Canal RB, Pacheco RC, et al. Experimental infection of the opossum Didelphis aurita by Rickettsia felis, Rickettsia bellii, and Rickettsia parkeri and evaluation of the transmission of the infection to ticks Amblyomma cajennense and Amblyomma dubitatum. Vector Borne Zoonotic Dis 2010; 10(10): 959-967. http://dx.doi.org/10.1089/vbz.2009.0149. PMid:20455783.

Joppert AM, Hagiwara MK, Yoshinari NH. Borrelia burgdorferi antibodies in dogs from Cotia county, São Paulo State, Brazil. Rev Inst Med Trop Sao Paulo 2001; 43(5): 251-255. http://dx.doi.org/10.1590/S003646652001000500003. PMid:11696846.

Krupka M, Raska M, Belakova J, Horynova M, Novotny R, Weigl E. Biological aspects of Lyme disease spirochetes: Unique bacteria of the Borrelia burgdorferi species group. Biomed Pap Med Fac Univ Palacky Olomouc Czech Repub 2007; 151(2): 175-186. http://dx.doi.org/10.5507/ bp.2007.032. PMid:18345249.

Labruna MB. Ecology of Rickettsia in South America. Ann N Y Acad Sci 2009; 1166(1): 156-166. http://dx.doi.org/10.1111/j.17496632.2009.04516.x. PMid:19538276.

Madureira RC, Corrêa FN, Cunha NC, Guedes DSJ, Fonseca AH. Ocorrência de anticorpos homólogos anti-Borrelia burgdorferi em equinos de propriedades dos municípios de Três Rios e Vassouras, estado do Rio de Janeiro. Rev Bras Ci Vet 2007; 14(1): 43-46.

Milagres BS, Padilha AF, Barcelos RM, Gomes GG, Montandon CE, Pena DC, et al. Rickettsia in synanthropic and domestic animals and their hosts from two areas of low endemicity for Brazilian spotted fever in the eastern region of Minas Gerais, Brazil. Am J Trop Med Hyg 2010; 83(6): 1305-1307. http://dx.doi.org/10.4269/ajtmh.2010.10-0239. PMid:21118939.

Montandon CE, Yoshinari NH, Milagres BS, Mazioli R, Gomes GG, Moreira HN, et al. Evidence of Borrelia in wild and domestic mammals from the state of Minas Gerais, Brazil. Rev Bras Parasitol Vet 2014; 23(2): 287-290. http://dx.doi.org/10.1590/S1984-29612014040. PMid:25054516. 
Oliver JH Jr. Biology and systematics of ticks (Acari: Ixodida). Annu Rev Ecol Syst 1989; 20(1): 397-430. http://dx.doi.org/10.1146/annurev. es.20.110189.002145.

Parola P, Paddock CD, Socolovschi C, Labruna MB, Mediannikov O, KernifT, et al. Update on Tick-Borne Rickettsioses around the World: a geographic approach. Clin Microbiol Rev 2013; 26(4): 657-702. http:// dx.doi.org/10.1128/CMR.00032-13. PMid:24092850.

Pinter A, Labruna MB. Isolation of Rickettsia rickettsii and Rickettsia bellii in cell culture from the tick Amblyomma aureolatum in Brazil. Ann N Y Acad Sci 2006; 1078(1): 523-529. http://dx.doi.org/10.1196/ annals.1374.103. PMid:17114770.
Silveira I, Martins TF, Olegário MM, Peterka C, Guedes E, Ferreira F, et al. Rickettsial infection in animals, humans and ticks in Paulicéia, Brazil. Zoonoses Public Health 2015; 62(7): 525-533. http://dx.doi. org/10.1111/zph.12180. PMid:25643912.

Steere AC. Lyme disease. N Engl J Med 2001; 345(2): 115-125. http:// dx.doi.org/10.1056/NEJM200107123450207. PMid:11450660.

Yoshinari NH, Mantovani E, Bonoldi VLN, Marangoni RG, Gauditano G. Doença de Lyme-Símile Brasileira ou Síndrome Baggio-Yoshinari: zoonose exótica e emergente transmitida por carrapatos. Rev Assoc Med Bras 2010; 56(3): 363-369. http://dx.doi.org/10.1590/S010442302010000300025 . PMid:20676548. 